\title{
Elektroniczne budżety obywatelskie w największych miastach Polski
}

\section{Wprowadzenie}

Budżet obywatelski, jak zwykło się określać budżet partycypacyjny w Polsce, to proces decyzyjny, w którym mieszkańcy danej jednostki samorządu terytorialnego współdecydują o wydatkowaniu środków publicznych w ramach projektów zgłoszonych przez nich samych. Budżet obywatelski powinien mieć następujące cechy: przejrzystość i otwartość, przestrzeń do dyskusji, charakter planistyczny oraz powinien stanowić wsparcie aktywności mieszkańców i być rozsądny z finansowego punktu widzenia ${ }^{1}$. Stworzenie budżetu obywatelskiego jest procesem długotrwałym, a jego wyniki powinny mieć charakter wiążący. Choć charakteru wiążącego nie mają konsultacje społeczne, to właśnie regulacje prawne ich dotyczące są podstawą do wprowadzania bardziej szczegółowych przepisów prawnych umożliwiających realizację zasad budżetu obywatelskiego w Polsce.

Celem niniejszego opracowania jest próba odpowiedzi na pytanie, czy w ramach funkcjonujących w największych miastach w Polsce głosowań w ramach budżetów obywatelskich wykorzystywane są środki komunikacji elektronicznej, a jeżeli tak, to w jakim stopniu obywatele korzystają z tych narzędzi.

${ }^{1}$ D. Kraszewski, K. Mojkowski, Budżet obywatelski w Polsce, http://www.batory.org. pl/upload/files/Programy\%20operacyjne/Masz\%20Glos/Budzet_obywatelski_w_Polsce_D._Kraszewski_K._Mojkowski.pdf (dostęp: 20 II 2016). 
Badaniem objętych zostało pięć największych miast w Polsce, wyłonionych na podstawie danych Głównego Urzędu Statystycznego prezentujących liczbę ludności na dzień 31 grudnia 2014 r. ${ }^{2}$ Wszystkie miasta mają ponad 500 tysięcy mieszkańców, a są to: Warszawa, Kraków, Łódź, Wrocław i Poznań.

Tabelaryczne zestawienie największych miast w Polsce

\begin{tabular}{|l|l|r|r|r|}
\hline \multicolumn{1}{|c|}{ Miasto } & \multicolumn{1}{c|}{ Województwo } & Ogólem & Mężczyźni & Kobiety \\
\hline Warszawa & mazowieckie & 1735442 & 796192 & 939250 \\
\hline Kraków & małopolskie & 761873 & 355242 & 406631 \\
\hline Łódź & łódzkie & 706004 & 321304 & 384700 \\
\hline Wrocław & dolnośląskie & 634487 & 295950 & 338537 \\
\hline Poznań & wielkopolskie & 545680 & 254316 & 291364 \\
\hline
\end{tabular}

Źródło: Miasta największe...

Analiza obejmowała wszystkie budżety obywatelskie przeprowadzone $w$ badanych jednostkach od momentu ich uruchomienia $w$ danej jednostce do roku 2015. Badanie obejmowało:

- weryfikację aktów prawnych będących podstawą wprowadzania budżetów,

- możliwości elektronicznego zgłaszania projektów przez obywateli,

- liczbę projektów zgłoszonych, zakwalifikowanych do głosowania i wybranych,

- frekwencję, z uwzględnieniem podziału na głosy oddane elektronicznie i tradycyjnie.

Dane statystyczne objęte badaniem ustalone zostały na podstawie informacji upublicznionych w Internecie, w postaci dokumentów ewaluacyjnych opublikowanych w Warszawie ${ }^{3}$ i Krakowie $^{4}$, natomiast

${ }^{2}$ Miasta największe pod względem ludności, Główny Urząd Statystyczny, http://stat.gov. $\mathrm{pl} /$ statystyka-regionalna/rankingi-statystyczne/miasta-najwieksze-pod-wzgledem-liczby-ludnosci/ (dostęp: 7 II 2016).

${ }^{3}$ Raport $z$ budżetu partycypacyjnego za rok 2015, Warszawa, 14 VIII 2014 r., http:// twojbudzet.um.warszawa.pl/sites/twojbudzet.um.warszawa.pl/files/raport_-_budzet_ partycypacyjny_2015.pdf (dostęp: 7 II 2016) oraz Raport z konsultacji społecznych z mieszkańcami m.st. Warszawy w zakresie budżetu partycypacyjnego na rok 2016, http://twojbudzet. um.warszawa.pl/sites/twojbudzet.um.warszawa.pl/files/raport_-_budzet_partycypacyjny_na_rok_2016.pdf (dostęp: 7 II 2016).

${ }^{4}$ Ewaluacja pierwszej edycji Budżetu Obywatelskiego w Krakowie, Warszawa-Kraków, listopad 2014, https://www.google.pl/url?sa=t\&rct=j\&q=\&esrc=s\&source=web\&cd= 
w przypadku Łodzi, Wrocławia i Poznania uzyskanych w drodze przekazania informacji na podstawie ustawy o dostępie do informacji publicznej ${ }^{5}$.

\section{Podstawy prawne}

Artykuł 5a ustawy o samorządzie gminnym ${ }^{6}$ stanowi, że w przypadkach przewidzianych tą ustawą oraz w innych sprawach ważnych dla gminy moga być prowadzone na jej terytorium konsultacje z mieszkańcami gminy. Wówczas to zasady i tryb przeprowadzania tych konsultacji będzie określała uchwała rady gminy (w miastach: uchwała rady miasta), czyli organu stanowiącego tej jednostki samorządu terytorialnego. Uszczegółowienie przepisów uchwały rady miasta znajduje odzwierciedlenie $\mathrm{w}$ zarządzeniach prezydentów miast będących organem wykonawczym jednostki samorządu terytorialnego. Przepisy powyższe znajdujące zastosowanie w poszczególnych miastach zostaną wskazane w dalszej części opracowania.

Regulacja art. 5a ustawy o samorządzie gminnym stanowi swego rodzaju rekompensatę za brak możliwości stosowania współcześnie demokracji bezpośredniej. $W$ ten sposób następuje powrót do demokracji uczestniczącej ${ }^{7}$. Sięganie w tym przypadku do form demokracji bezpośredniej ma zapewnić władzom lokalnym potwierdzenie bądź dezaprobatę ich działań oraz daje organom gminy większą legitymację w zakresie sprawowania władzy ${ }^{8}$.

$2 \&$ cad $=$ rja\&uact $=8 \&$ ved $=0$ ahUKEwjP-oTGuffKAhXIEywKHdSHD5kQFgglMAE \&url= http\%3A\%2F\%2Fwww.krakow.pl\%2Fzalacznik\%2F207941\&usg=AFQjCNEFWOJaJZWSiUoV97wFAHQFP91Rig\&sig2=qFWaH9yxuyzXBLoTUaJyEg (dostęp: 14 II 2016) oraz Ewaluacja drugiej edycji Budżetu Obywatelskiego w Krakowie, Warszawa-Kraków, październik 2015, https://www.google.pl/url?sa=t\&rct=j\&q=\&esrc=s\&source=web\&cd=3\&ved=0ahUKEwjP-oTGuffKAhXIEywKHdSHD5kQFggrMAI\&url=http \%3A\%2F\%2Fkrakow.pl\%2Fzalacznik\%2F244718\&usg=AFQjCNE38p-fFCDHevNDPpoLxNpATWpQpA\&sig2=E8YDZpWhN0G0Adw6Q2qFHA (dostęp: 7 II 2016).

${ }^{5}$ Ustawa z dnia 6 IX 2001 r. o dostępie do informacji publicznej (tekst jedn. Dz.U. Nr 112, poz. 1198 ze zm.).

${ }^{6}$ Ustawa z dnia 8 III 1990 r. o samorządzie gminnym (tekst jedn. Dz.U. 1990 Nr 16, poz. 95 ze zm.).

${ }^{7}$ Z. Niewiadomski, Przepisy ogólne, w: Ustawa o samorzadzie gminnym. Komentarz $z$ odniesieniami do ustaw o samorzadzie powiatowym i samorządzie województwa, pod red. R. Hausera, Z. Niewiadomskiego, Warszawa 2011, s. 66.

${ }^{8}$ B. Dolnicki, Przepisy ogólne, w: Ustawa o samorządzie gminnym. Komentarz, pod red. B. Dolnickiego, Warszawa 2010, s. 88. 
Ustawa o samorządzie gminnym wskazuje wiele aktywności, w przypadku których przeprowadzenie konsultacji społecznych jest obowiązkowe $^{9}$. Jednakże redakcja art. 5a tej ustawy świadczy o tym, że konsultacje są możliwe również $\mathrm{w}$ innych wypadkach, ważnych z punktu widzenia mieszkańców gminy. Należy do nich zaliczyć konsultacje dotyczące budżetu obywatelskiego. W literaturze podkreśla się ${ }^{10}$, że konsultacje stanowią alternatywę dla referendum gminnego. Wspólną cechą konsultacji i referendum jest zamiar wysondowania opinii, poglądów, stanowisk. Różnią się one natomiast skutkiem, gdyż referendum ma charakter wiążący, a konsultacje mają jedynie charakter opiniodawczy $^{11}$. Jednakże, choć wynik konsultacji nie wiąże organu podejmującego określone działanie, to organ powinien je uzasadnić, gdy podejmuje decyzje wbrew wynikowi konsultacji, a brak takiego uzasadnienia należy traktować jako naruszenie prawa. Inny pogląd w sprawie oznaczałby w istocie fasadowe traktowanie instytucji konsultacji społecznych i powodował skutek odwrotny do zamierzonego przez ustawodawcę ${ }^{12}$. Na gruncie tej uwagi Z. Niewiadomskiego należy wskazać, że odstąpienie przez organy gminy od wyników wyborów w zakresie budżetu obywatelskiego bez odpowiedniego uzasadnienia takiego działania stanowić będzie naruszenie prawa, dające podstawę do jego egzekwowania.

W literaturze wskazuje się $e^{13}$ ponadto, że z brzmienia art. 5 ust. 2 ustawy o samorządzie gminnym ${ }^{14}$ można wywnioskować, iż rada gminy powinna ustalać tryb i zasady przeprowadzenia konsultacji społecznych odrębnie dla każdej sprawy. Potrzeba taka wynika niekiedy

${ }^{9}$ Art. 4 a ust. 1 oraz art. 5 ust. 2 ustawy o samorządzie gminnym przewidują przeprowadzenie konsultacji społecznych w następujących przypadkach:

- tworzenie, łączenie, podział i znoszenie gmin oraz ustalanie ich granic;

- nadanie gminie lub miejscowości statusu miasta i ustalenie jego granic;

- ustalenie lub zmiana nazwy gminy oraz siedziby jej władz;

- utworzenie jednostki pomocniczej.

${ }^{10}$ A. Szewc, G. Jyż, Z. Pławecki, Przepisy ogólne, w: iidem, Ustawa o samorządzie gminnym. Komentarz, Warszawa 2010, s. 86.

${ }^{11}$ Więcej na temat przedmiotu referendum i konsultacji w wyroku Naczelnego Sądu Administracyjnego z dnia 28 II 2001 r., sygn. II SA/Ld 297/01, Centralna Baza Orzeczeń Sądów Administracyjnych, http://orzeczenia.nsa.gov.pl/doc/0177F314F3 (dostęp: 31 III 2016).

12 Z. Niewiadomski, op. cit., s. 66.

${ }_{13}$ A. Szewc, G. Jyż, Z. Pławecki, op. cit., s. 87.

${ }^{14}$ Stanowi on, iż "jednostkę pomocniczą tworzy rada gminy, w drodze uchwały, po przeprowadzeniu konsultacji z mieszkańcami lub z ich własnej inicjatywy". 
ze specyfiki konsultowanego problemu lub innych okoliczności. Nie ma jednak przeszkód, aby rada gminy unormowała sprawę w sposób ogólny, np. w uchwale o zasadach i trybie przeprowadzenia konsultacji z mieszkańcami gminy. Przedmiotowa analiza nasunęła pewne wnioski w odniesieniu do powyższego postulatu, które zostaną zaprezentowane w dalszej części opracowania. Natomiast brak jakiejkolwiek regulacji prawnej, uniemożliwiający $\mathrm{w}$ istocie ocenę prawidłowości przeprowadzenia konsultacji, godzi generalnie w funkcję tej instytucji. Ponadto powoduje, że podejmowane pozornie przez gminę działania nie stanowią w rzeczywistości czynności przeprowadzanych w ramach konsultacji ${ }^{15}$. Przeprowadzenie konsultacji generalnie, to znaczy bez względu na ich charakter (fakultatywny czy obligatoryjny), powinno zostać poprzedzone podjęciem przez radę gminy uchwały określającej zasady i tryb prowadzenia konsultacji ${ }^{16}$.

Artykuł 5a ustawy o samorządzie gminnym nie upoważnia organów gminy do ustalania kategorii podmiotów uprawnionych do udziału w konsultacjach. Kompetencja zawarta w tym przepisie upoważnia rady gminy jedynie do określenia zasad i trybu przeprowadzenia konsultacji $^{17}$. To stanowisko sądów administracyjnych ${ }^{18}$ jest nieprzestrzegane

${ }^{15}$ Wyrok Wojewódzkiego Sądu Administracyjnego (WSA) w Gliwicach z 6 III 2007 r., sygn. IV SA/Gl 1500/06, http://orzeczenia.nsa.gov.pl/doc/FFF8787BE7 (dostęp: 31 III 2016).

${ }^{16}$ Wyrok Trybunału Konstytucyjnego (TK) z 25 III 2003 r., sygn. U 10/01, http:// trybunal.gov.pl/rozprawy-i-ogloszenia-orzeczen/wyroki-i-postanowienia/art/5506-ustalanie-granic-gmin/ (dostęp: 31 III 2016). W wyroku z 27 XI 2000 r., sygn. U. 3/00, TK stwierdził, że "wykładnia językowa, jak i systemowa art. 5a ust. 2 ustawy o samorządzie gminnym świadczy o intencji ustawodawcy przypisania radzie gminy kompetencji do określania zasad i trybu przeprowadzania konsultacji zarówno w przypadkach konsultacji przewidzianych ustawą, jak i konsultacji «fakultatywnych», przeprowadzanych «w innych sprawach ważnych dla gminy». Instytucja konsultacji z mieszkańcami, o której mowa w art. 4 ust. 1 ustawy o samorządzie gminnym, stanowi niewątpliwie jeden z przypadków konsultacji przewidzianych w ustawie. Tym samym jej przeprowadzenie również winno być poprzedzone podjęciem przez radę gminy uchwały określającej zasady i tryb takiej konsultacji".

${ }^{17}$ Wyrok WSA w Opolu z 13 VI 2006 r., sygn. II SA/Op 213/06, http://orzeczenia.nsa. gov.pl/doc/38A010B7F7 (dostęp: 31 III 2016). W wyroku tym sąd stwierdził, że „wykładnia celowościowa wskazuje na potrzebę utożsamienia pojęcia mieszkaniec gminy z pojęciem osoby stale zamieszkującej na obszarze tej gminy. Ponieważ w zasadzie miejsce zamieszkania zależne jest od zamiaru, a więc od woli konkretnej osoby, a o charakterze pobytu decydują również okoliczności faktyczne wskazujące na zamiar rzeczywisty, przeto osoby, które spełniają wymienione przesłanki, są mieszkańcami gminy, żadne inne kryteria nie powinny decydować o uznaniu danej osoby za mieszkańca gminy".

${ }^{18}$ Zaprezentowane również w wyroku WSA we Wrocławiu z 29 IV 2011 r., sygn. III Sa/Wr 20/11, http://orzeczenia.nsa.gov.pl/doc/1B6B341F35 (dostęp: 31 III 2016), 
na gruncie organizacji budżetów obywatelskich. Jak zostanie wykazane poniżej, czy to w uchwałach odnoszących się do konsultacji społecznych, czy to w zarządzeniach organów wykonawczych, katalog uprawnionych do udziału w konsultacjach jest określany w sposób subiektywny, często zmienia się z każdym rokiem.

Należy podkreślić, że tożsame przepisy w odniesieniu do organizacji konsultacji społecznych zawierają art. 3d ustawy o samorządzie powiatowym ${ }^{19}$ oraz art. 10a ustawy o samorządzie województwa ${ }^{20}$, co oznacza, iż zachowują one aktualność w odniesieniu do organizowania wszelkiego rodzaju elektronicznych konsultacji również na tych szczeblach, z zachowaniem różnic co do liczebności podmiotów konsultowanych.

Powinność przeprowadzania konsultacji społecznych na szczeblu lokalnym wynika nie tylko z powyższych przepisów, ale również z art. 4 ust. 6 Europejskiej Karty Samorządu Lokalnego ${ }^{21}$, stanowiącego, że społeczności lokalne powinny być konsultowane o tyle, o ile jest to możliwe, we właściwym czasie i w odpowiednim trybie, w trakcie opracowywania planów oraz podejmowania decyzji we wszystkich sprawach ich bezpośrednio dotyczących.

oraz w wyroku WSA w Opolu z 12 VI 2006 r., sygn. II SA/Op 207/06, http://orzeczenia. nsa.gov.pl/doc/167503286A (dostęp: 31 III 2016). Wojewódzki Sąd Administracyjny we Wrocławiu stwierdził, że kompetencja organu gminy zawarta w art. 5a ustawy o samorządzie gminnym "nie obejmuje określania praw podmiotowych warunkujących uprawnienie mieszkańców gminy do udziału w konsultacjach. Istotnym jest, iż krąg osób uprawnionych do udziału w konsultacjach społecznych został określony przez samego ustawodawcę. Są nimi mieszkańcy gminy, czyli osoby zamieszkujące w miejscowości położonej na jej obszarze z zamiarem stałego pobytu. Pojęcie mieszkańca nie jest tożsame $z$ pojęciem osoby posiadającej czynne prawo wyborcze. Fakt pozbawienia praw publicznych, praw wyborczych czy też ubezwłasnowolnienia mieszkańca gminy nie jest jednoznaczny z pozbawieniem go prawa udziału w konsultacjach". Wojewódzki Sąd Administracyjny w Opolu rozstrzygał natomiast sprawę dotyczącą uchwały rady powiatu, ale podobnie stwierdził w swym rozstrzygnięciu, że „rada powiatu nie posiada ustawowej delegacji (kompetencji) do zawężania kręgu osób uprawnionych do wzięcia udziału w konsultacjach tylko do tych mieszkańców powiatu, którzy posiadają czynne prawo wyborcze do rady powiatu. Dookreślenie w ten sposób kręgu osób uprawnionych do uczestniczenia w konsultacjach stanowi rażące naruszenie prawa materialnego, bowiem w uprawnieniu rady powiatu do ustanowienia zasad i trybu przeprowadzania konsultacji nie mieści się określenie praw podmiotowych członków społeczności lokalnej w zakresie prawa jednostki do udziału w konsultacjach".

${ }^{19}$ Ustawa z dnia 5 VI 1998 r. o samorządzie powiatowym (Dz.U. Nr 91, poz. 578 ze zm.).

${ }^{20}$ Ustawa z dnia 5 VI 1998 r. o samorządzie województwa (Dz.U. Nr 91, poz. 576 ze $\mathrm{zm}$.).

${ }^{21}$ Europejska Karta Samorządu Lokalnego, sporządzona w Strasburgu dnia $15 \mathrm{X}$ 1985 r. (Dz.U. 1994 Nr 124, poz. 607 ze zm.). 


\section{Budżet obywatelski jako element e-participation}

Budżet obywatelski powinien być również badany pod kątem wykorzystania w nim Internetu, a więc jako element elektronicznego rządu (e-government). E-government to dziedzina multidyscyplinarna, na którą można spojrzeć z punktu widzenia nauk informatycznych, administracyjnych czy politycznych, oraz dyscyplina, na którą składają się tak istotne działy, jak: e-demokracja, e-uczestnictwo, e-administracja, e-zdrowie czy e-sądownictwo ${ }^{22}$. Elektroniczny budżet można rozpatrywać zarówno z punktu widzenia e-demokracji, jak i e-uczestnictwa. E-demokracja rozumiana jako działania obejmujące bezpośredni kontakt pomiędzy wybranym przedstawicielem narodu a obywatelem bądź na szczeblu centralnym, bądź przez przedstawiciela lokalnego ${ }^{23}$ jest rozpatrywana jako nowa forma demokracji reprezentatywnej ${ }^{24}$.

W skład tak rozumianej e-demokracji wchodzą elektroniczne głosowania, elektroniczne zaangażowanie obywateli, elektroniczne konsultacje i elektroniczna kontrola. Pod pojęciem elektronicznego głosowania (e-voting) rozumie się głosowanie za pomocą urządzeń elektronicznych. Mogą one służyć elektronicznej rejestracji głosujących, elektronicznemu przeliczaniu głosów, czy wręcz elektronicznemu oddawaniu głosów za pomocą określonego narzędzia, zwłaszcza Internetu ${ }^{25}$. Elektroniczne zaangażowanie (e-engagement) to włączenie obywateli w sprawy publiczne za pomocą środków komunikacji elektronicznej; elektroniczne konsultacje (e-consultation) to wymiana opinii, poglądów, zdań pomiędzy urzędnikami a obywatelami; zaś elektroniczna kontrola (e-controllership) to weryfikacja przez obywateli kosztów i jakości wykonania planowanych usług czy inwestycji.

${ }^{22}$ U. Löfstedt, E-Services for and by Citizens. Towards e-Participation and Social Systems Design for Development of Local Public e-Services, Östersund 2008, s. 13.

${ }^{23}$ S. Bhatnagar, Unlocking E-Government Potential. Concepts, Cases and Practical Insights, New Delhi 2009, s. 4-6; S.C.J. Palvia, S.S. Sharma, E-Government and E-Governance: Definitions/Domain Framework and Status Around the World, 2007, r., http://www.iceg.net/2007/ books/1/1_369.pdf (dostęp: 30 VI 2015); P.G. Nixon, A. Grebner, L. Sudulich, Challengers to Traditional E-Government (non-governmental actors), w: P.G. Nixon, V.N. Koutrakou, R. Rawal, Understading E-Government in Europe. Issues and Challenges, New York 2010, s. 246.

${ }^{24}$ M. Margolis, G. Moreno-Riaño, E-Government, Customers and Citizens, w: P.G. Nixon, V.N. Koutrakou, R. Rawal, op. cit., s. 87.

${ }^{25}$ N. Kersting, H. Baldersheim, Electronic Voting and Democratic Issues: An Introduction, w: Electronic Voting and Democracy: A Comparative Analysis, ed. by N. Kersting, H. Baldersheim, New York 2004, s. 5. 
Wszystkie powyższe formy aktywizacji obywateli w życiu publicznym określa się również pojęciem elektronicznego uczestnictwa (e-participation). Jedną z podstawowych form elektronicznego uczestnictwa może być budżet obywatelski. Jest on narzędziem służącym realizacji nie tylko elektronicznego głosowania czy elektronicznych konsultacji, ale również elektronicznego zaangażowania lub kontroli. W obecnie funkcjonujących elektronicznych budżetach obywatelskich głosy oddawane są za pomocą Internetu, same zaś budżety stanowią wyraz konsultacji społecznych, pozwalają zaangażować obywateli w życie społeczności lokalnej, wpłynąć na jej rozwój, a także zweryfikować wykonanie budżetu pod kątem jakościowym i finansowym. Inaczej rzecz ujmując, elektroniczne budżety obywatelskie są narzędziem pozwalającym w pełni realizować zamierzenia stojące za ideą elektronicznego uczestnictwa obywateli. Elektroniczne budżety obywatelskie będą elementem kontaktu G2C ${ }^{26}$, umożliwiającego obywatelom uzyskanie informacji czy dostarczenie usługi on-line.

Warto podkreślić, że skorzystanie z konsultacji w ramach budżetu obywatelskiego w Polsce nie wymaga, obowiązkowych w innych przypadkach, narzędzi, takich jak podpis elektroniczny czy profil zaufany ePUAP (Elektronicznej Platformy Usług Administracji Publicznej $)^{27}$. Weryfikacja głosujących $\mathrm{w}$ ramach budżetu obywatelskiego odbywa się poprzez podanie miejsca zamieszkania, numeru PESEL (Powszechny Elektroniczny System Ewidencji Ludności) czy numeru dowodu osobistego. Tego rodzaju ułatwienia, podobne do tych, które występują w ramach elektronicznych podatków, gdzie koniecznym do weryfikacji elementem jest podanie kwoty przychodu za rok poprzedni, powinny zachęcać do czynnego uczestnictwa mieszkańców największych polskich miast w głosowaniach nad budżetami obywatelskimi.

\section{Budżety obywatelskie w polskich miastach}

Podstawą prawną budżetów obywatelskich w mieście stołecznym Warszawie jest uchwała nr LXI/1691/2013 Rady Miasta Stołecznego Warszawy z dnia 11 lipca 2013 r. w sprawie zasad i trybu

\footnotetext{
${ }^{26}$ Government to Citizen, czyli pomiędzy państwem a obywatelami.

${ }^{27}$ Wymaganych Ustawą z dnia 17 II 2005 r. o informatyzacji działalności podmiotów realizujących zadania publiczne (tekst jedn. Dz.U. Nr 64, poz. 565 ze zm.).
} 
przeprowadzania konsultacji z mieszkańcami m.st. Warszawy ${ }^{28}$. Na jej podstawie wydane zostały zarządzenia prezydenta miasta stołecznego Warszawy określające zasady organizacji dotychczasowych budżetów obywatelskich w Warszawie, to znaczy zarządzenie nr 5409/2014 z dnia 13 stycznia 2014 r. oraz zarządzenie nr 6699/2014 z dnia 16 października $2014 \mathrm{r}$. W przypadku obydwu budżetów istniała możliwość zgłaszania przez obywateli projektów do realizacji listownie, drogą mailową albo osobiście. W budżecie obywatelskim 2014 zgłoszono 2236 projektów, z czego po weryfikacji pod głosowanie poddano 1390 projektów. W budżecie obywatelskim 2015 zgłoszono 2333 projekty, z czego po weryfikacji pod głosowanie poddano 1464 projekty. W obydwu przypadkach projekty były podzielone na projekty lokalne oraz projekty ogólnodzielnicowe.

Zarówno w budżecie obywatelskim 2014, jak i 2015 uprawnionym do głosowania był każdy mieszkaniec m.st. Warszawy, w tym również osoby małoletnie (za zgodą przedstawicieli ustawowych) oraz cudzoziemcy. W obydwu wypadkach istniała możliwość głosowania w wyznaczonych punktach poprzez złożenie karty do głosowania do przeznaczonej do tego urny, w formie elektronicznej z wykorzystaniem poczty e-mail lub w formie korespondencyjnej (listownie). W przypadku pierwszego budżetu obywatelskiego organizowanego w Warszawie każdy głosujący mógł oddać głos na maksymalnie pięć projektów. W głosowaniu wybrano do realizacji 336 projektów. W głosowaniu tym 72,33\% głosów zostało oddanych elektronicznie, a $27,6 \%$ w sposób tradycyjny. W przypadku drugiego budżetu obywatelskiego każdy mógł oddać głos na dowolną liczbę projektów z zastrzeżeniem, że suma kosztów realizacji wybranych projektów nie mogła przekroczyć dostępnej puli na poziomie dzielnicowym lub określonym obszarze terytorialnym. W głosowaniu wybrano do realizacji 644 projekty. W głosowaniu tym 58,9\% głosów zostało oddanych elektronicznie, a 41,09\% w sposób tradycyjny.

W pierwszym budżecie obywatelskim wzięły udział 166893 osoby, a w drugim 172395 osób.

Podobnie jak w Warszawie, również w Krakowie odbyły się w badanym okresie dwie edycje budżetów obywatelskich. Ich podstawę stanowiły dwie różne uchwały rady miasta. Podstawą organizacji budżetu obywatelskiego 2014 była uchwała nr XCVII/1465/14 Rady Miasta Krakowa z dnia 20 lutego 2014 r. w sprawie budżetu obywatelskiego

${ }^{28}$ Dz.Urz. Województwa Mazowieckiego 2013, poz. 8442. 
miasta Krakowa ${ }^{29}$ i wydane na jej podstawie zarządzenie nr 2621/14 Prezydenta Miasta Krakowa z dnia 19 września 2014 r. Podstawą organizacji budżetu obywatelskiego 2015 była uchwała nr VII/107/15 Rady Miasta Krakowa z dnia 11 lutego 2015 r. w sprawie Regulaminu budżetu obywatelskiego Miasta Krakowa ${ }^{30}$ i wydane na jej podstawie zarządzenie nr 1463/2015 Prezydenta Miasta Krakowa z dnia 12 czerwca 2015 r. W przypadku obydwu budżetów istniała możliwość zgłaszania projektów do realizacji przez wszystkich mieszkańców Krakowa, którzy ukończyli 16. rok życia, osobiście, listownie lub mailowo. W budżecie obywatelskim 2014 zgłoszono 656 projektów, z czego po weryfikacji pod głosowanie poddano 436 projektów. W budżecie obywatelskim 2015 zgłoszono 627 projektów, z czego po weryfikacji pod głosowanie poddano 464 projekty. W obydwu przypadkach projekty były podzielone na projekty dzielnicowe oraz projekty ogólnomiejskie.

Zarówno w budżecie obywatelskim 2014, jak i 2015 uprawnionym do głosowania był każdy mieszkaniec Krakowa, który ukończył 16. rok życia. W obydwu wypadkach istniała możliwość głosowania przez portal internetowy lub w punktach głosowania na terenie miasta. W przypadku pierwszego budżetu obywatelskiego organizowanego w Krakowie, aby głos był ważny, należało zagłosować na dziesięć projektów (pięć dzielnicowych i pięć ogólnomiejskich). W głosowaniu wybrano do realizacji 68 projektów. W głosowaniu tym $88 \%$ głosów zostało oddanych elektronicznie, a $12 \%$ w sposób tradycyjny. $W$ przypadku drugiego budżetu obywatelskiego, aby głos był ważny, należało zagłosować na sześć projektów (trzy dzielnicowe i trzy ogólnomiejskie). W głosowaniu wybrano do realizacji 108 projektów. W głosowaniu tym $76 \%$ głosów zostało oddanych elektronicznie, a $24 \%$ w sposób tradycyjny. W pierwszym budżecie obywatelskim wzięło udział 67320 osób, a w drugim 48462 osoby.

W badanym okresie w Łodzi odbyły się trzy edycje budżetów obywatelskich. Wszystkie były oparte na tej samej uchwale Rady Miejskiej w Łodzi, to znaczy uchwale nr XXXVIII/695/12 z dnia 25 kwietnia 2012 r. w sprawie wprowadzenia Regulaminu Konsultacji Społecznych ${ }^{31}$. Na jej podstawie wydane zostały trzy zarządzenia będące podstawą organizacji budżetów obywatelskich 2013, 2014 i 2015. Były to: zarządzenie nr 3971/VI/13 Prezydenta Miasta Łodzi z dnia 2 kwietnia 2013 r.,

\footnotetext{
${ }^{29}$ Dz.Urz. Województwa Małopolskiego 2014, poz. 1554.

${ }^{30}$ Dz.Urz. Województwa Małopolskiego 2015, poz. 826.

${ }^{31}$ Dz.Urz. Województwa Łódzkiego 2012, poz. 1786.
} 
zarządzenie nr 5837/VI/14 Prezydenta Miasta Łodzi z dnia 5 marca 2014 r. oraz zarządzenie nr 644/VII/15 Prezydenta Miasta Łodzi z dnia 17 marca 2015 r. W przeciwieństwie do budżetów organizowanych w Warszawie czy Krakowie, w Łodzi projekty do realizacji mogły być zgłaszane jedynie osobiście lub listownie. Nie było zatem możliwości elektronicznego składania propozycji. W budżecie obywatelskim 2013 zgłoszono 908 projektów, z czego po weryfikacji pod głosowanie poddano 762 projekty. W budżecie obywatelskim 2014 zgłoszono 871 projektów, z czego po weryfikacji pod głosowanie poddano 751 projektów. W budżecie obywatelskim 2015 zgłoszono 645 projektów, z czego po weryfikacji pod głosowanie poddano 531 projektów. We wszystkich przypadkach projekty były podzielone na projekty lokalne oraz projekty ogólnomiejskie.

We wszystkich organizowanych w Łodzi budżetach obywatelskich uprawnionym do głosowania był każdy mieszkaniec Łodzi, który ukończył 16. rok życia. We wszystkich przypadkach istniała możliwość głosowania za pomocą aplikacji internetowej, osobiście lub korespondencyjnie. We wszystkich przypadkach każdy mógł oddać głos maksymalnie na dziesięć zadań (pięć projektów lokalnych i pięć projektów ogólnomiejskich). W pierwszym głosowaniu wybrano do realizacji 47 projektów. W głosowaniu tym 79\% głosów zostało oddanych elektronicznie, a 21\% w sposób tradycyjny. W drugim głosowaniu wybrano do realizacji 65 projektów. Oddano na nie 71,5\% głosów elektronicznie i 28,5\% głosów w sposób tradycyjny. W budżecie obywatelskim 2015 wybrano do realizacji 67 projektów. W głosowaniu tym $50 \%$ głosów oddanych zostało elektronicznie, a $50 \%$ w sposób tradycyjny.

W pierwszym budżecie obywatelskim wzięło udział 128499 osób, w drugim 174834 osoby, a w ostatnim 135277 osób.

Podobnie jak w Łodzi, również we Wrocławiu budżet obywatelski był organizowany trzykrotnie. Pierwszy budżet obywatelski 2013 miał charakter pilotażowy. Wszystkie oparte były jedynie na uchwale Rady Miejskiej Wrocławia. Nie były w tym zakresie wydawane zarządzenia prezydenta miasta, które uszczegóławiałyby zasady organizacji budżetu obywatelskiego. Uchwała ta to uchwała nr XXXVII/2437/05 Rady Miejskiej Wrocławia z dnia 21 kwietnia 2005 r. w sprawie zasad i trybu przeprowadzania konsultacji z mieszkańcami Wrocławia ${ }^{32}$. We wszystkich trzech budżetach projekty mogły być zgłaszane osobiście,

\footnotetext{
${ }^{32}$ Dz.Urz. Województwa Dolnośląskiego 2005 Nr 101, poz. 2151.
} 
listownie lub mailowo. W budżecie obywatelskim 2013 zgłoszono 240 projektów, z czego po weryfikacji pod głosowanie poddano 129 projektów. W budżecie obywatelskim 2014 zgłoszono 483 projekty, z czego po weryfikacji pod głosowanie poddano 314 projektów. W budżecie obywatelskim 2015 zgłoszono 817 projektów, z czego po weryfikacji pod głosowanie poddano 545 projektów. W budżecie obywatelskim 2013 nie było podziału projektów, natomiast w budżetach 2014 i 2015 projekty były podzielone na trzy grupy ze względu na progi kwotowe.

W pilotażowym budżecie obywatelskim uprawnieni do głosowania byli wszyscy pełnoletni mieszkańcy Wrocławia, natomiast w budżetach obywatelskich 2014 i 2015 do głosowania dopuszczeni byli ponadto studenci kształcący się we Wrocławiu. We wszystkich przypadkach istniała możliwość głosowania w formie elektronicznej lub papierowej. W pierwszej edycji budżetu obywatelskiego we Wrocławiu każdy mógł oddać maksymalnie pięć głosów, w edycji drugiej można było głosować na maksymalnie trzy projekty niezależnie od progów kwotowych, natomiast w edycji 2015 każdy mógł oddać głos na maksymalnie trzy projekty z trzech różnych progów kwotowych. W pierwszym głosowaniu wybrano do realizacji osiem projektów. W głosowaniu tym 96\% głosów zostało oddanych elektronicznie, a $4 \%$ w sposób tradycyjny. W drugim głosowaniu wybrano do realizacji 89 projektów. Oddano na nie $84 \%$ głosów elektronicznych i $16 \%$ głosów tradycyjnych. W budżecie obywatelskim 2015 wybrano do realizacji 79 projektów. W głosowaniu tym $76 \%$ głosów oddanych zostało elektronicznie, a $24 \%$ w sposób tradycyjny. W pierwszym budżecie obywatelskim wzięło udział 51708 osób, w drugim 153366 osób, a w ostatnim 168278 osób.

Poznań to jedno z miast, które jako pierwsze organizowało budżet obywatelski. W badanym okresie odbyły się tu cztery edycje budżetu obywatelskiego. Wszystkie oparte są na jednej uchwale Rady Miasta Poznania, to jest uchwale nr LXXX/1200/V/2010 z dnia 9 listopada 2010 r. w sprawie zasad i trybu przeprowadzania konsultacji społecznych na terenie miasta Poznania ${ }^{33}$. Na jej podstawie wydane zostały cztery zarządzenia, które były podstawą organizacji budżetów obywatelskich w poszczególnych latach. Były to następujące akty prawne: zarządzenie nr 564/2012/P Prezydenta Miasta Poznania z dnia 10 sierpnia 2012 r., zarządzenie nr 415/2013/P Prezydenta Miasta Poznania z dnia 14 czerwca 2013 r., zarządzenie nr 224/2014/P Prezydenta Miasta Poznania z dnia

${ }^{33}$ Dz.Urz. Województwa Wielkopolskiego 2011 Nr 18, poz. 418. 
18 kwietnia 2014 r. oraz zarządzenie nr 306/2015/P Prezydenta Miasta Poznania z dnia 11 maja 2015 r. We wszystkich edycjach budżetu obywatelskiego w Poznaniu istniała możliwość składania projektów zarówno w wersji papierowej, jak i elektronicznie. W budżecie obywatelskim 2012 zgłoszono 265 projektów, z czego po weryfikacji dokonanej przez specjalny zespół (dokonujący oceny merytorycznej, nie tylko formalnej) pod głosowanie poddano 20 projektów. W budżecie obywatelskim 2013 zgłoszono 217 wniosków, z czego podobnie jak w roku poprzednim pod głosowanie poddano jedynie 20 projektów wskazanych przez specjalny zespół. W budżecie obywatelskim 2014 zgłoszono 205 projektów, z czego po weryfikacji pod głosowanie poddano 30 projektów (10 dużych i 20 małych). Natomiast w budżecie obywatelskim 2015 zgłoszono 272 projekty, z czego po weryfikacji pod głosowanie poddano 168 projektów. $\mathrm{W}$ pierwszych dwóch edycjach zgłoszone projekty nie były w żaden sposób dzielone. W budżecie obywatelskim 2014 projekty były podzielone na małe i duże ze względu na progi kwotowe. W ostatniej edycji budżetu projekty były już podzielone na dzielnicowe i ogólnomiejskie.

W Poznaniu w każdej edycji budżetu obywatelskiego w różny sposób określane były zasady dotyczące osób uprawnionych do głosowania. W roku 2012 głosować mogli jedynie mieszkańcy Poznania posiadający czynne prawo wyborcze. W roku 2013 grupa ta została poszerzona o osoby studiujące w Poznaniu, które mogły głosować na podstawie numeru legitymacji studenckiej. W kolejnym roku grupa ta została jeszcze bardziej poszerzona i włączono do niej mieszkańców Poznania, którzy ukończyli 16. rok życia, o ile byli zameldowani w Poznaniu. W edycji z roku 2015 wprowadzono jedną zasadę, że uprawnionymi do głosowania są po prostu wszyscy mieszkańcy Poznania, którzy ukończyli 16. rok życia. W każdej edycji istniała możliwość głosowania osobiście $\mathrm{w}$ wyznaczonych w tym celu punktach lub przez Internet. W pierwszych dwóch edycjach istniała możliwość głosowania maksymalnie na pięć projektów, w kolejnych dwóch na maksymalnie sześć projektów. Przy czym w budżecie obywatelskim 2014 głosy musiały być podzielone pomiędzy trzy projekty małe i trzy projekty duże. W pierwszym głosowaniu wybrano do realizacji pięć projektów. W głosowaniu tym $45 \%$ głosów zostało oddanych elektronicznie, a 55\% w sposób tradycyjny. W drugim głosowaniu wybrano do realizacji cztery projekty. Oddano na nie 55\% głosów elektronicznie i 45\% głosów w sposób tradycyjny. W budżecie obywatelskim 2014 wybrano do realizacji sześć projektów (trzy duże i trzy małe). W głosowaniu tym $38 \%$ głosów oddanych zostało 
elektronicznie, a $62 \% \mathrm{w}$ sposób tradycyjny. W budżecie obywatelskim 2015 wybrano do realizacji 38 projektów. Oddano na nie 72,5\% głosów elektronicznie i $27,5 \%$ głosów w sposób tradycyjny. W pierwszym budżecie obywatelskim wzięło udział 20238 osób, w drugim 88597 osób, w trzecim 54277 osób, a w ostatnim 73136 osób.

\section{Analiza danych}

Podstawowy wniosek, jaki nasuwa się po analizie budżetów obywatelskich pod kątem frekwencji oraz wykorzystania w nich narzędzi elektronicznych, dotyczy spadku liczby głosów oddanych elektronicznie w stosunku do liczby głosów oddanych drogą tradycyjną, czyli papierową. Trend ten przedstawia poniższy wykres 1 .

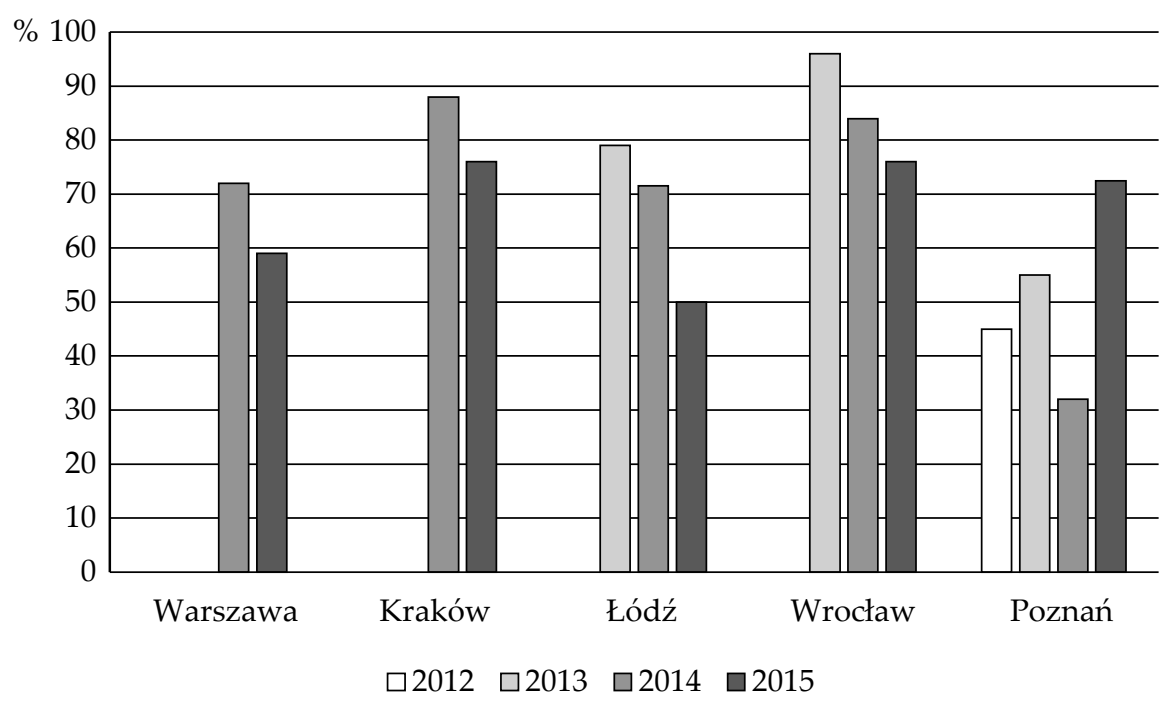

Wykres 1. Głosy oddane elektronicznie w latach 2012-2015

Źródło: Opracowanie własne na podstawie danych przytoczonych w punkcie 3 niniejszego opracowania.

Z jednym wyjątkiem miasta Poznania, które wymyka się wszelkim schematom (nie można określić stałego wzrostu lub spadku w wykorzystaniu elektronicznych narzędzi głosowania), w $80 \%$ badanych podmiotów co roku spada liczba głosów oddanych elektronicznie. Trudno określić przyczyny takiego stanu rzeczy. Zasady odnoszące się do głosowań są w badanych podmiotach niezmienne. Może to być ściśle 
związane z nieufnością obywateli w Polsce do elektronicznych form głosowania, w szczególności w kontaktach z organami administracji publicznej. Zaufanie jest bardzo ważnym elementem, który często okazuje się istotną barierą przy użyciu środków on-line. Brak zaufania do organów administracji publicznej, który wykształcił się wśród polskich obywateli, przenosi się na usługi świadczone elektronicznie. Polscy obywatele wybierają osobistą wizytę w urzędzie przed komunikacją drogą elektroniczna, która wymaga relatywnie dużego zaufania do instytucji, z którą kontakt ten następuje. Brak zaufania jest podstawą wielu barier przy załatwianiu spraw przez Internet w Polsce. Najczęstsze bariery zostały przedstawione na wykresie 2 .

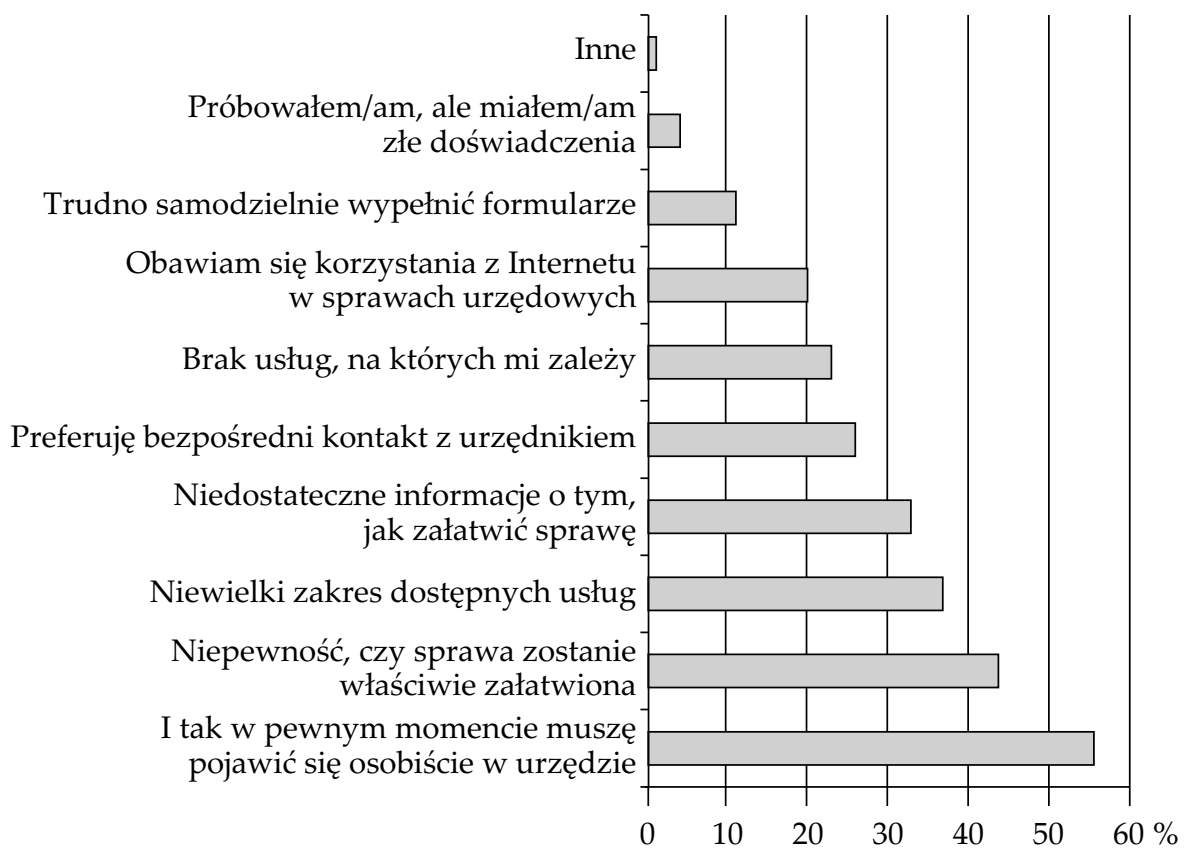

Wykres 2. Bariery przy załatwianiu spraw przez Internet

Źródło: Bariery przy załatwianiu spraw przez Internet, IT w Administracji, luty 2011, s. 8.

Należy wskazać, że we wszystkich edycjach budżetów obywatelskich podmioty objęte badaniem organizowały różne formy aktywizowania mieszkańców - od spotkań na etapie zgłaszania projektów po kampanie reklamowe poprzedzające głosowanie. Kampanie informacyjne obejmowały różne formy rozpowszechniania informacji: telewizje lokalne, 
radio, plakaty na autobusach, przystankach, w miejscach użyteczności publicznej itp.

Ponadto w części badanych podmiotów (np. w Krakowie) organizacji budżetów obywatelskich towarzyszyły informacje o próbie oszustwa dotyczącego głosów oddanych elektronicznie dokonanej w celu doprowadzenia do zwycięstwa jednego z projektów. Tego typu doniesienia z pewnością zintensyfikowały obawy wśród mieszkańców danego ośrodka.

Ważny wniosek, jaki nasuwa się po analizie przedmiotowych danych, odnosi się do bardzo niskiej frekwencji obywateli w organizowanych w badanym okresie budżetach obywatelskich. Choć miasta nie podają frekwencji, czasami ją tylko szacując, jak np. w przypadku Krakowa, który ocenił ją odpowiednio na $10 \%$ i $8 \%$, to widać, że odsetek głosujących wśród mieszkańców miast jest niewielki. Władze nie podają frekwencji w budżetach obywatelskich, ponieważ w głosowaniach biorą również udział osoby, które jedynie deklarują, że są mieszkańcami danego miasta, a nie są w nim zameldowane (na pobyt stały bądź czasowy), przez co nie można jednoznacznie określić liczby osób uprawnionych do głosowania. W związku z tym dane, którymi posługują się miasta, to dane o liczbie głosujących.

Kolejny wniosek nasuwający się po analizie procedur związanych z organizacją budżetów obywatelskich dotyczy braku ich ewaluacji. Tylko w dwóch z pięciu badanych podmiotów, to jest w Warszawie ${ }^{34}$ i w Krakowie ${ }^{35}$, władze miast dokonały wnikliwej analizy przeprowadzonych procedur, wskazując na ich mocne i słabe strony oraz wskazując kierunki rozwoju. Ewaluacja nie powinna być zjawiskiem epizodycznym, ale przygotowywanym co roku, wnikliwym raportem wskazującym kierunki zmian. Tak jak miasta i ich mieszkańcy zmieniają się, tak budżet obywatelski powinien być odpowiedzią na zachodzące zmiany. Należy stwierdzić, że tego rodzaju ewaluacja powinna stać się standardem jednostek organizujących tego typu konsultacje, pozwalającym na uniknięcie pojawiających się błędów w przyszłości. Błędy bowiem wciąż występują. W dostępnych ewaluacjach wskazuje się między innymi na trudności w realizacji wybranych projektów (bezpośrednio wpływające na ocenę tej instytucji przez mieszkańców) czy złą lub bardzo złą współpracę z przedstawicielami władz miasta na etapie realizacji projektów.

\footnotetext{
${ }^{34}$ Raport z budżetu partycypacyjnego za rok 2015, op. cit.

${ }^{35}$ Ewaluacja pierwszej edycji Budżetu Obywatelskiego w Krakowie, op. cit., oraz Ewaluacja drugiej edycji Budżetu Obywatelskiego w Krakowie, op. cit.
} 
Dość trudnym zadaniem jest również odnalezienie jasnej i przejrzystej informacji o budżetach na stronach internetowych jednostek. Problem ten może być jednakże w sposób sprawny ominięty dzięki współpracy ze strony podmiotów poprzez zastosowanie procedury uzyskania informacji na wniosek w drodze ustawy o dostępie do informacji publicznej.

Podniesiony na początku opracowania problem prawnego ujęcia zagadnienia konsultacji w odniesieniu do budżetu obywatelskiego w osobnej uchwale również był widoczny w przeprowadzonych badaniach. Należy wskazać, że konsultacje w zakresie budżetów obywatelskich są tak specyficznym zagadnieniem o istotnym znaczeniu, iż powinny one znaleźć unormowanie w odrębnej uchwale uprawnionego podmiotu. Po przeprowadzonej analizie można stwierdzić, że badane podmioty zastosowały trojakiego rodzaju rozwiązanie. Najczęściej występującym jest ogólna regulacja zawarta w uchwale dotyczącej spraw związanych z konsultacjami społecznymi wykorzystywana przy każdej edycji budżetu obywatelskiego, uszczegóławiana jednakże z każdym rokiem w odrębnych zarządzeniach prezydentów miast. Taka praktyka ma miejsce w Warszawie, Łodzi i Poznaniu. Kolejnym zastosowanym rozwiązaniem, które należy ocenić najwyżej zarówno ze względu na szczegółowość zapisów, jak i powszechność dostępnych informacji, jest każdorazowe unormowanie kwestii w osobnej uchwale organu stanowiącego, a ponadto w osobnym, co roku tworzonym, akcie wykonawczym. Taką metodę w badanym okresie zastosowano w Krakowie. Dzięki takiemu podejściu nie ma wątpliwości co do zakresu podmiotów uprawnionych do głosowania, sposobów przeprowadzania tego głosowania oraz ewentualnie powstałych kwestii wątpliwych. Ostatni ze sposobów regulujących tę kwestię, który a contrario należy ocenić najniżej, to ujęcie zagadnienia w ramach jednej ogólnej regulacji odnoszącej się do konsultacji społecznych, a zawartej w uchwale organu stanowiącego i będącej jedyną podstawą prawną organizacji budżetu obywatelskiego. Taką praktykę zastosowano we Wrocławiu. Powodować ona może pewne niejasności i brak precyzji. Wymaga również dużo większego wysiłku w zakresie odnalezienia danych dotyczących organizacji poszczególnych edycji budżetu obywatelskiego.

Podkreślenia wymaga fakt, że właśnie w kierunku odrębnych uchwał jednostek samorządu terytorialnego w każdej ze spraw podlegających konsultacji zdaje się iść praktyka ${ }^{36}$.

\footnotetext{
${ }^{36}$ Z. Niewiadomski, op. cit., s. 68.
} 


\section{Podsumowanie}

Tworzenie budżetów obywatelskich jest obecnie zjawiskiem globalnym. W Polsce ich historia rozpoczęła się w roku 2011, kiedy to pierwsza tego rodzaju forma angażowania obywateli w sprawy bezpośrednio ich dotyczące została zaproponowana w Sopocie - mieście liczącym 37654 obywateli $^{37}$. Następnie budżety obywatelskie zaczęły pojawiać się w kolejnych, większych miastach Polski, by podać przykład Poznania, w którym to budżet obywatelski pojawił się już w roku 2012. Obecnie większość polskich miast proponuje tego rodzaju aktywność swoim mieszkańcom. Choć w procesie uchwalania budżetu obywatelskiego proponuje się wykorzystanie narzędzi elektronicznych w sposób stosunkowo prosty, zauważyć należy, że ani sama procedura, ani też narzędzia elektroniczne w niej wykorzystywane nie cieszą się szczególnym zainteresowaniem obywateli. Przyczyn takiego stanu rzeczy może być wiele (np. nietrafione kampanie reklamowe, brak zaufania do organów administracji publicznej). Spadek wykorzystania narzędzi elektronicznych jest wielce niepokojący. Brak ewaluacji wprowadzonych rozwiązań w większości jednostek nie pozwala na zgłębienie problemu. Ponadto w badanych jednostkach nie prowadzi się badań porównawczych, które mogłyby być pomocne w rozwiązywaniu pojawiających się problemów.

Należy wskazać, że podmioty objęte badaniem proponują obywatelom kolejne elektroniczne formy aktywności. Przykładowo, w Poznaniu uruchomiona została geoankieta, czyli aplikacja internetowa umożliwiająca uzyskanie odpowiedzi od użytkowników poprzez oznaczanie obiektów na mapie. Geoankieta ma zostać wykorzystana w procesach planowania przestrzennego, planowania transportu czy rewitalizacji. Inicjatywy tego rodzaju zasługują na bardzo pozytywną ocenę, jednakże dopóki podobne działania nie będą objęte pogłębioną analizą i ewaluacją, samorządy wciąż będą borykać się z niską frekwencją lub spadkiem udziału elektronicznych form angażowania obywateli.

Wniosek sformułowany na podstawie przeprowadzonej analizy dotyczący spadku wykorzystania narzędzi elektronicznych w budżetach obywatelskich organizowanych w największych miastach w Polsce oznacza spadek elektronicznego uczestnictwa w ogólności w rozumieniu przedstawionym na wstępie niniejszego opracowania. Biorąc pod

\footnotetext{
${ }^{37}$ Miasta największe...
} 
uwagę, jak niewiele form zaangażowania obywateli występuje w Polsce w tym znaczeniu, trend ten należy tym bardziej ocenić negatywnie.

\section{ELECTRONIC PARTICIPATORY BUDGETING IN LARGEST POLISH CITIES}

\section{Sum mary}

Electronic participatory budgeting is becoming an important element of social consultations. The legal ground for its operation at the municipal level is provided in Article $5 \mathrm{a}$ of the Act of municipal self-government. The organisation of participatory budgeting is a manifestation of direct democracy that allows citizens to express their approval or disapproval of the actions taken by local authorities. It also reflects the level of citizen e-participation in public life. In Poland e-participation is still at a developing stage and therefore needs to be further researched in comparative studies.

This article is an attempt to determine whether in the largest cities in Poland e-participation is used in voting on city budgets and if the answer if in the affirmative, which e-tools are available and used, and to what extent. By analysing relevant and applicable legislation, the possibility of electronic filing of projects as well as the number of e-voters have been researched. All budgeting processes taking place in Warszawa, Kraków, Łódź, Wrocław and Poznań since 2015, when the project started, have been examined.

Citizen participatory budgeting as such started in Poland in 2011. However, the largest cities continue to encounter difficulties in their proper implementation. Resorting to electronic tools has not helped much, what is more, some municipal bodies, for the sake of least complexity, sometimes resign even from the use of electronic signature. If this is the case, a question may be asked about the reason for such poor e-participation of Polish citizens in this one of the few anyway, forms of e-participation available in Poland.

Keywords: citizen participatory budget - social consultations - e-participation e-democracy, e-government 